\title{
Islamic Modernism and the Development of Islamic Intellectualism
}

\author{
Nur Fauziah ${ }^{1}$, Didin Saepudin ${ }^{2}$, Amany Lubis $^{3}$, Hamka Hasan ${ }^{4}$, \\ Kusmana $^{5}$ \\ \{nurfauziah1590@gmail.com¹, didin.saepudin@uinjkt.ac.id ${ }^{2}$, amany.lubis@uinjkt.ac.id ${ }^{3}$, \\ hamka.hasan@uinjkt.ac.id ${ }^{4}$, kusmana@uinjkt.ac.id ${ }^{5}$ \} \\ Sy arif Hiday atullah State Islamic University of Jakarta, Indonesia ${ }^{1,2,3,4,5}$
}

\begin{abstract}
This paper discusses Islamic modernism and the development of Islamic intellectualism. The method used is a descriptive analysis method using a historical approach. The aim is to determine the comparison of Islamic modernism and the development of Islamic intellectualism of Jamaluddin al-Afghani, Muhammad Abduh, and Muhammad Rasyid Ridha. First, the renewal of Jamaluddin Al-Afghani greatly appreciates the values of intellectualism that come from the West, especially in the fields of philosophy, science, and technology. He advised Muslims to develop reason and technology as has been adopted by Western nations. Jamaluddin Al-Afghani believes that mastering science, technology, and cultivating the scientific tradition of the Ummah will accelerate progress and increase the strength of Islam. Second, Muhammad Abduh's renewal is more focused on improving the fate and future of the Egyptian people. His thinking is more oriented to the aspects of education and the condition of Muslims. Education is very influential in the progress and awakening of Muslims in the field of science. Third, Rasyid Ridha developed a renewal of his thoughts which he got from Muhammad Abduh. Rasyid Ridha's thinking about renewal is more focused on the field of education. However, Rasyid Rida was less familiar with the traditions of Western thought than al-Afghani and Abduh.
\end{abstract}

Keywords: Modernism, Intellectualism, Islamic Modernism, Islamic Intellectualism.

\section{Introduction}

The golden age, decline, and revival of Islamic reform have passed. Of course, many challenges affect them. The main factor causing the decline of Muslims occurred because they were far from the teachings of Islam as the main source, namely: the Word of Allah, namely the Al-Qur'an, and the hadith of the Prophet.[1]

The existence of schools and sectarianism resulted in the division of Muslims. Also, the West was dominating, the politics of fighting against each other were rampant and the excessive fanaticism towards the schools was getting stronger.[2] The development of science is decreasing, due to the construction of Muslim thinking. This is a factor that causes the decline of Muslims. Meanwhile, philosophy, science, and technology are developing and advancing rapidly in Western countries. Thus, the West can rule the world, including the Islamic world.[3]

The Islamic world before the 19th century experienced a period of colonization and decline. The beginning of the 19th century was the beginning of a renewal of the revival of 
rational thinking of Muslims. At that time, the Islamic world and the modern West intersected. Muslims are starting to realize that by thinking rationally, Islamic teachings that have long been abandoned, will be easily understood again. Thus, the thought of understanding Islamic teachings will again become a new spirit for the progress and development of the Islamic world in the future.[3]

This paper will try to examine Islamic Modernism and the Development of Islamic Intellectualism, as well as Islamic modernism intellectual figures. The presenter only presented three figures who were very influential in the renewal of Islamic modernism.

\section{Islamic Modernism}

The term modernization in Islamic terminology is called renewal and improvement. renewal and improvement have the same essence, namely reviewing and reflecting on and interpreting new contextual understandings of the situations and challenges of the times. [4]

Western countries, provide an understanding of modernism as efforts made to make changes to deviant understandings and customs that develop in society. Also, modernism is a thought, a flow, a movement to make changes following the new conditions brought about by modern science and technology.[5]

Modernism is the process of entering a foreign culture into society.[6] Therefore, modernism cannot be separated from globalization which has implications for changes in the social and intellectual order. Globalization is an inseparable secularization is sue. Globalization and secularization seem to be a unity that occurs in the West and East which cannot be separated.[7]

Is lamic modernism occurred in the early 19th century. The initial phase of the reformation of Muslims. Muslims began to rise and develop through the path of ijtihad. The West is getting ahead and Muslims are falling further behind. Both in terms of philosophy, science, and technology. At that time, different responses emerged among Muslims. Respond based on their Is lamic style.[8]

First Response, Muslims must acknowledge their downturn and backwardness from Western countries and must rise from adversity by reforming by following Western countries. The second response is to refuse and leave whatever comes from the West without being ignored. The second response believes that Muslims must return to the main source, namely the Al-Qur'an and Hadith because Islam is the best not by following Western countries.[8]

Furthermore, Nurcholis Madjid expressed his opinion about modernization. That modernization is thinking rationally by involving moral dimensions, by holding fast to the principle of faith, namely faith in Allah. Besides, Nurcholis Madjid completely rejects that modernization is westernization. Because westernization is secularism related to atheism. Meanwhile, atheism is the pinnacle of secularism. [9]

The most important goal of modernization in line with the teachings of Islam is rationalization, whatever is done and done requires consideration of reason. With rationalization, Muslims will be encouraged to be critical in dealing with problems and leave taqlid which is strictly prohibited in Islam by reforming. Thus, modernization does not contradict the basic teachings of Islam.[10] However, modernization is a balance between action and reason in doing anything to make changes that are considered good.

Modern groups argue that Muslims today need to make interpretations (interpretations) of Islamic teachings. Muslims must make changes to open the gates of ijtihad and avoid 
taqlid.[11] In other words, modernism has an open attitude in understanding the source of teachings and believes that there is still room for Muslims to carry out ijtihad and leave blind taqlid which is prohibited by religion.

Modern Islamic groups are religious reform movements that carry out reforms by adopting ideas from modern thinkers such as Al-Afghani and Abduh.

Al-Afghani and Abduh made reforms and left blind taqlid to the madhab priests and emphasized the importance of ijtihad in facing changes in the Muslim community. Modernist Muslims try to improve the progress of Muslim civilization by taking a scientific approach to understanding Islamic teachings. For this, they call for an invitation to refer to the Qur'an and Hadith which are the main sources, and advocate a flexible and sustainable reinterpretation of Islamic teachings.[12]

The renewal of Islam started with Muhammad Abduh's meeting with Jamaluddin AlAfghani. Philosophy and socio-political science are being expanded. Religious practice must be seen and examined which ones require change and which cannot be changed. This change was made by convincing the Muslims not to give up, to remain strong and not waver in des pair and destruction. However, it continues to make updates in all fields.[13]

Sayyid Jamaluddin Al-Afghani was a reformist figure who was very focused and concerned about the condition of the Muslims at that time. He tried his best to revive Muslims and carry out reforms employing ijtihad. In the Islamic world, Sayyid Jamaluddin Al-Afghani is known as Mujaddid and Mujahid. One of the reformers who changed the mindset of Muslims.

The factors behind the reforms in Egypt carried out by modern Islamic thinkers: first, Islamic teachings began to be tainted by superstition, khurafat, and heresy, and the Egyptian society was increasingly left behind and backward from the Western world. Second, Western countries colonized the Islamic State, both in the economic, political, and religious fields. In this sense, it is known as Gold, Glory, and Gospel.[14]

Thus it can be concluded that Islamic modernization is a renewal of understanding that is more relevant to modern life. Islamic modernization seeks to interpret something to open the door to ijtihad. Besides, trying to avoid taqlid to the four madhab imams by thinking rationally in understanding and reflecting on Is lamic teachings. The goal is for the progress and glory of Muslims in the future.

\section{Development of Islamic Intellectualism}

Islamic intellectual development is divided into three eras. The three of them have different styles. ranging from classical, medieval, and modern times. The classical era began at the time of the Prophet, where the development of Islamic intellectuals was practiced by teaching and education which was carried out utilizing the method of writing and memorizing.[15]

In medieval times, Islamic intellectuals began to develop compared to classical times. Institutionalized institutions began to emerge through streams of theology, Sufism, and schools of thought. In medieval times this was the peak period of Islamic intellectual heyday.[15]

Furthermore, in modern times it is a struggle for Islamic intellectual traditions. Renewal of thought in understanding Islam is put forward. Modern times try to eradicate superstition, khurafat, and heresy that have shackled Muslims. Islamic teachings were returned to the AlQur'an and Hadith. Rational thinking awareness by performing ijtihad interpretation of Is lamic teachings is enforced.[15] 
The intellectual development of Islam returns Islam as a religion that gives truth in answering problems by promoting thought. This is because the problems of each era are constantly evolving and becoming increasingly complex. So it requires solving problems that are difficult to find. Therefore, ijtihad is needed as a way of renewal.

Jamaluddin Al-Afghani has his uniqueness and uniqueness towards renewal in Islam. The uniqueness and uniqueness of Jamaluddin Al-Afghani were seen when giving a response to the Western domination of Islam. Also, Al-Afghani was very moderate by accommodating ideas that came from the West. This was done to improve the decline of the ummah and the weakness of Islamic intellectuals. But on the other hand, Afghani was very firm in dealing with national problems related to Islam.[8]

The emergence of divisions among Muslims was the most important factor used by Western colonialism to colonize Muslims. Besides, the wealth of Muslims began to be taken over by Western colonialism. The lack of knowledge and understanding of science, both in Islamic sciences and other sciences, has made the intellectual spirit of Muslims begin to fade. Jamaluddin Al-Afghani comes with a very noble goal, namely to uphold nationalism, patriotism, and the glory of Islam. Of course, with full awareness and high intellectual enthusiasm and responsibility as a Muslim towards Muslims.

Jamaluddin Al-Afghani tried to awaken Muslims who were still in shadow and were shackled to the glory of Islam in the past. Even though at that time, the Muslim community was blocked by Western imperialism which had great strength. According to him, Islam should rise to reform and carry out intellectual movements, along with the pace of modern knowledge.[8]

Jamaluddin Al-Afghani was the main figure in the modernization of Islam, followed by his students, Muhammad Abduh, Rasyid Ridha until his thoughts reached Indonesia, which was brought by his students.

\section{Figures of Islamic Modernization}

\subsection{Jamaluddin Al-Afghani}

One of the figures for Islamic modernism is Jamaluddin Al-Afghani who was born in Asadabad (1255 H / 1838 AD). He died in Istanbul (1315H / 1897M). Jamaluddin Al-Afghani received the title Sayid which means the descendant of Husain bin Ali bin Abi Talib. His full name is Sayid Jamaluddin Al-Afghani. The name al-Afghani was taken from the country of his birth. Apart from Al-Afghani, Asabadi is his nickname.[16]

Jamaluddin Al-Afghani is a reformist figure in Islam who has creative ideas to restore the fighting spirit of Muslims. Besides, he was very firm and courageous in opposing the colonialism of the modern Western State and eliminating the attitude of imitation among the ummah, where this attitude of imitation has shackled the rational mindset of the people.[8]

His renewal thinking is based on the belief that Islamic teachings are in harmony with all nations, ages, and circumstances. Therefore, if it is found that Islamic teachings are deviating and not following the problems faced due to changing times, it can be adjusted with a new way of interpretation through ijtihad as written in the Al-Qur'an and Hadith. Because according to Jamaluddin Al-Afghani the door to ijtihad is still open.[17]

Therefore, if Islam wants to do ijtihad with new ideas, the Islamic world can compete with the Western world. 
Jamaluddin Al-Afghani argued that Muslims must unite in facing and freeing themselves from Western colonialism by forming a stronghold of political power. Its political ideas and strategies are based on the idea of pan Islamism (renewal by uniting all Muslims).[18] Pan Islamism is an effective bulwark against violations and domination of foreign powers against Muslim territory.[19]

However, he also showed an honest attitude in appreciating the values of intellectualism that came from the West, especially in the fields of philosophy, science, and technology. He advised Muslims to develop reason and technology as has been adopted by Western nations. He believes that mastery of science, technology, and cultivating the scientific tradition of the Ummah will accelerate progress and increase the strength of Islam.[18]

Jamaluddin Al-Afghani is a Muslim intellectual who reformed the Islamic tradition by reinterpreting the sources of Islamic teachings, which came from the Koran, Sunnah, Ijma ', and Qiyas to answer problems experienced by modern society in religious institutions in theoretical and practical terms.[20] Thus, Jamaluddin Al-Afghani's thoughts cover all aspects of the Islamic world.

\subsection{Muhammad Abduh}

Muhammad Abduh is a figure of Islamic reform in Egypt. He comes from Turkey. He was born in the village of Lower Egypt in 1849. His father was named Abduh Hasan Khaerullah. His mother was from the Arab nation and her lineage reached Umar ibn Khattab. They lived and settled in Mahallah Nasr.[21]

Muhammad Abduh was a reformer in the 19th century who had very bright ideas. Its renewal ideas cover various aspects of life. It can revive the fighting spirit of Muslims after experiencing the stagnation phase, especially in the advancement of science.[21]

Muhammad Abduh's reforms focused more on improving the fate and future of the Egyptian people. His thinking is more oriented to aspects of education and the condition of Muslims. He is a moderate nationalist who advocates the importance of preparing people who are responsible for the honor and progress of the nation.[21]

Islamic reform according to Muhammad Abduh does not only return to original teachings by purifying Islamic teachings from outside influences and practices that destroy the purity of Islam, but he invites reform of Islamic doctrine by the spirit of modern thought.[22] According to Muhammad Abduh, the backwardness of the Muslims was due to the weak education of the Muslims at that time. Both religious science and general science. Therefore, he considers that education is something that should get serious attention.

According to Muhammad Abduh, general science no longer has a place worthy of the hearts of Muslims, which should become a unit of knowledge that needs attention. General science is more widely adopted and even used comprehensively by the West. This is an internal factor for the waning of Is lamic educational values.[23]

Value education in Muhammad Abduh's thought was the beginning of the awakening of Muslims in the early 20th century. The idea of renewal was disseminated in the magazines A1Manar and Al-Urwatul Wusqa as a reference for reformist figures in the Islamic world.[21] Thus, Muhammad Abduh's renewal emphasized the educational aspect.

\subsection{Rasyid Ridha}

Rasyid Ridha argues that spiritual knowledge in Islamic teachings allows a person to get everything he wants. He strongly opposed Islamic teachings which said that worldly life was 
not important. Also, he strongly opposed awake and about excessive adoration and obedience to shaykhs and wali. Thus, Rasyid Ridha reformed Islamic teachings by returning to the true teachings.

Rasyid Ridha developed a renewal of his thoughts which he got from Muhammad Abduh through Al-Urwah Al-Wusqa magazine since he was in Syria, then moved to Egypt and became a student of Muhammad Abduh. Rasyid Ridha's thinking about renewing his life was not much different from his teacher. He also argued that Muslims experienced setbacks because they no longer adhere to pure Is lamic teachings.[24]

Rasyid Ridha argues that spiritual knowledge in Islamic teachings allows a person to get everything he wants. He strongly opposed Islamic teachings which said that worldly life was not important. Also, he strongly opposed awake and about excessive adoration and obedience to shaykhs and wali.[17] Thus, Rasyid Ridha reformed Islamic teachings by returning to the true teachings.[24]

Rasyid Ridha sangat menghargai akal manusia. Hal ini disebabkan karena akal dapat dipakai dalam menafsirkan ajaran-ajaran mengenai hidup bermasyarakat. Ijtihad dalam soal ibadah tidak lagi diperlukan. Ijtihad (fungsi eksplorasi akal) dapat dipergunakan terhadap ayat dan hadis yang masih samar yang tidak disebutkan secara langsung dalam al-Qur'an dan hadits. Di sinilah, menurut Rasyid Ridha, terletak dinamika Islam.[24]

\section{Conclusion}

Islamic modernism occurred in the 19th century. Islamic modernism is a renewal of understanding that is more relevant to modern life and the interpretation of something to open the door of ijtihad and avoid taqlid to the four imams of madhab by thinking rationally in understanding and reflecting Islamic teachings. The goal is for the progress and glory of Muslims in the future.

In essence, if Muslims carry out Ijtihad then Muslims are believed to be able to increase the progress of Islamic civilization. For that, they call for an invitation for Muslims to return to the Al-Qur'an and Hadith.

Jamaluddin Al-Afghani's reformation was based on the belief that Islamic teachings were compatible with all nations, ages, and circumstances. Therefore, if it is found that Islamic teachings are deviating and not by the problems faced due to changing times, it can be adjusted with a new way of interpretation through ijtihad as written in the Al-Qur'an and Hadith. Jamaluddin Al-Afghani also showed his honest attitude in appreciating the values of intellectualism that came from the West, especially in the fields of philosophy, science, and technology. He advised Muslims to develop reason and technology as has been adopted by Western nations. Jamaluddin Al-Afghani believes that mastering science, technology, and cultivating the scientific tradition of the Ummah will accelerate progress and increase the strength of Is lam.

Muhammad Abduh's renewal is more focused on improving the fate and future of the Egyptian people. His thinking is more oriented to the aspects of education and the condition of Muslims. Education is very influential in the progress and awakening of Muslims in the field of science.

Rasyid Ridha developed a renewal of his thoughts which he got from Muhammad Abduh. Rasyid Ridha's thinking about renewal is more focused on the field of education. However, Rasyid Rida was less familiar with the traditions of Western thought than al-Afghani and 
Abduh.

Acknowledgments: This research is supported by The Graduate School of Islamic Studies UIN Syarif Hidayatullah. 


\section{References}

[1] M. Hasbullah, "A CENTURY OF NU-MUHAMMADIYAH IN INDONESIA: THE FAILURE OF ISLAMIC MODERNISM?," 2014.

[2] A. Munir, Aliran Modern Dalam Islam. Jakarta: Rineka Cipta, 1994.

[3] H. Nasution, Islam Ditinjau dari Berbagai Aspek. Jakarta: UI Press V, 1988.

[4] "Prof. Dr. Nurcholish madjid: jejak pemikiran dari pembaharu sampai guru bangsa / penulis, Jalaluddin Rakhmat... [et al.]; penyunting, Sukandi A.K. | OPAC Perpustakaan Nasional RI." https://opac.perpusnas.go.id/DetailOpac.aspx?id=718602 (accessed Aug. 18, 2020).

[5] H. Nasution, Islam Rasional Gagasan dan Pemikiran. Bandung: Mizan, 1995.

[6] Sukamto, Kepemimpinan Kyai dalam Pesantren. Jakarta: LP3IS, 1999.

[7] R. H. Lauer, Perspektif tentang Perubahan Sosial. Jakarta: Rineka Cipta, 2003.

[8] A. Hawi, "PEMIKIRAN JAMALUDDIN AL-AFGHANI (JAM AL AD-DIN AL-AFGHANI) (1838 - 1897 M)," Medina-Te J. Stud. Islam, vol. 13, no. 1, pp. 9-24, Oct. 2017, doi: 10.19109/medinate.v13i1.1536.

[9] N. Madjid, Islam KeModernan dan KeIndonesiaan,. Bandung: Mizan, 1998.

[10] S. Suaidi, "ISLAM DAN MODERNISME," Islam. J. Stud. Islam, vol. 1, no. 1, Jan. 2014, doi: 10.19105/islamuna.v1i1.558.

[11] Musa Yusuf Owoyemi dan Muhammad Mumtaz Ali, "The Compatibility of Islam with Modernity: A Brief Discourseon Muslim Reformists' Response," J. Islam Asia, no. 02, p. 336, 2011. [12] J. L. E. dalam Y. Suryana, Tradisionalisme dan Modernisme Islam Indonesia. Yogyakarta: Gapura Publishing, 2012.

[13] Abd sani, Lintasan Sejarah Pemikiran Perkembangan Modern Dalam Islam. Jakarta: Grafindo Persada, 2012.

[14] Y. Asmuni, Pengantar Studi Pemikiran dan Gerakan Pembaharuan dalam Islam. Jakarta: Rajawali Press, 1998.

[15] F. Fadhly, Tradisi Intelektual Islam Indonesia. 2018.

[16] Noorthaibah, "PEMIKIRAN PEMBAHARUAN JAMALUDDIN AL-AFGHANI: STUDI PEMIKIRAN KALAM TENTANG TAKDIR,” Dec. 2015. Accessed: Aug. 18, 2020. [Online]. Available: https://journal.iain-samarinda.ac.id/index.php/fenomena/article/view/305.

[17] H. Nasution, Pembaharuan dalam Islam Sejarah Pemikiran dan Gerakan. Jakarta: Bulan Bintang, 1975.

[18] Mukti Ali, Alam Pikiran Modern di Timur Tengah. .

[19] Fazlur Rahman, Islam. Chicago: The University of Chicago Press, 1979.

[20] The Oxford Dictionary of Islam. Oxford University Press, 2003.

[21] S. Pemikiran et al., "Studi Pemikiran Muhammad Abduh dan Pengaruhnya terhadap Pendidikan di Indonesia," Universitas Islam Negeri Sultan Maulana Hasanuddin, 2017.

[22] Alfian, Muhammadiyah The Political Behavior of A Muslim Modernist Organization Under Dutch Colonialism. .

[23] A. W. Muqoyyidin, "PEMBARUAN PENDIDIKAN ISLAM MENURUT MUHAMMAD ABDUH."

[24] H. M. Kasim, "MUHAMMAD RASYID RIDHA (Antara Rasionalisme \& Tradisionalisme)." 